\title{
Research on Writing Samples from the Perspective of Metadiscourse
}

\author{
Weixuan $\mathrm{Shi}^{1} \&$ Jikun $\mathrm{Han}^{1}$ \\ ${ }^{1}$ School of Foreign Languages, North China Electric Power University, Baoding, China \\ Correspondence: Weixuan Shi, School of Foreign Languages, North China Electric Power University, No. 689, \\ Huadian Road, Baoding, China. Tel: 86-137-2221-4052. E-mail: shiweixuan3458@126.com
}

$\begin{array}{ll}\text { Received: August 25, } 2014 & \text { Accepted: September 26, } 2014 \quad \text { Online Published: October 23, } 2014 \\ \text { doi:10.5539/elt.v7n11p151 } & \text { URL: http://dx.doi.org/10.5539/elt.v7n11p151 }\end{array}$

\begin{abstract}
Writing, as an advanced model of output, not only conveys the subject but also realizes the communication between readers and writers. Metadiscourse can help writers arrange and organize the discourse to influence readers' understanding of the text and their attitude towards its content. Taking writing samples of College English Test Band 4 (CET-4) as corpus, the research aims to explore the use of metadiscoure markers in high score writing group (HG) and low score writing group (LG). The research questions to be addressed in the study are as follows: 1) What are the similarities and differences between the two groups in the quantity and the types of metadiscourse markers? 2) What are the similarities and differences between the two groups in choosing metadiscourse markers? 3) What's the overall distribution of the inappropriately used metadiscourse markers in two groups? The research results show that there is a positive relation between proper use of metadiscourse markers and writing quality. This paper puts forward the strategies of improving the students' ability in the proper use of metadiscourse markers in English writing teaching.
\end{abstract}

Keywords: English writing teaching, metadiscourse, metadiscourse markers, writing

\section{Introduction}

In recent years, the passing rate of CET-4 and CET- 6 has obviously increased, but writing as an advanced model of output is a weak part in examinations and practices. Since last century lots of scholars have done many researches on how to improve students' writing ability. Most of them paid more attention to the specific language skills such as the correct use of grammar and vocabulary in writing while they neglected that writing is an inherent communication between writers and readers.

Language is a tool used for human communication. There are two levels of discourse in any form of language - the primary discourse level and the metadicourse level. On the primary discourse level, propositional information which consists of propositions and referential meanings is supplied. On the metadicourse level, the propositional material is not added but metadiscourse can help readers organize, interpret and react to such material. Metadiscourse is linguistic material in texts. Metadiscourse is concerned with the non-propositional content of the discourse, and academic circles once paid little attention to it. Recently, researchers both at home and abroad have done further researches on the functions of metadiscourse. They found that metadiscourse not only supports the propositional content of discourse but also is an effective device to enhance the readability and persuasiveness of the propositional content. It plays an important role in the organization of discourse, the delivery of the writer's attitude towards the discourse and the interaction between writers and readers. Nowadays, metadiscourse attracts more and more linguists' attention and scholars explore the features and rules of metadiscourse in academic articles, educational discourse, advertising slogans and business discourse. Besides, some studies also show its important role in the second language writing.

Although the theories with a focus on writing functions have been introduced into China, the present situation of English writing teaching is unsatisfactory. For one thing, many teachers still pay attention to the vocabulary, phrases, sentences and the structures of discourse in writing teaching. For another, our college students lack the understanding of metadiscourse and they are not good at making use of metadiscourse in writing, thus resulting in the low level of writing ability. So it will be helpful to improve students' writing ability, if metadiscourse is introduced into English writing teaching. 


\section{Literature Review}

\subsection{Metadiscourse}

\subsubsection{Definitions of Metadiscourse}

Since Harris put forward the term of "metadiscourse" in 1959, it has attracted much attention. Williams is the first scholar to use metadiscourse, and defines it as "writing about writing, whatever does not refer to the subject matter being addressed" (1981, p. 47). Hyland (2005) defines meta-discourse as the cover term for the self-reflective expressions used to negotiate interactional meanings in a text, assisting the writer (or) speaker to express a viewpoint and engage with readers as members of a particular community. "Metadiscourse embodies the idea that communication is more than just the exchange of information, goods or services, but involves the personality, attitudes and assumptions of those who are communicating" (Hyland, 2005, p. 3).

Cheng (1994, 1997, 1999, 2008), a Chinese scholar, translates "matediscourse" into "yayuyan". Li translates it into "yuanhuayu", and defines metadiscourse as "words, phrases or sentences which can be put anywhere and which add no more information to the utterance but which play an important role in marking the organization of utterance and embodying the intention of utterance. They, attached to the utterance, are not the subjects of the utterance but adjust the subjects in the communication" (2001, p. 44).

In a word, metadiscourse is a device used to arrange utterances, express writer's attitude towards the utterances and influence reader's reaction towards the propositions.

\subsubsection{Functions of Metadiscourse}

Halliday (1994) regards language as a system of signs and pays attention to the functions of language in actual communication. He points out three metafunctions of language: ideational function, textual function and interpersonal function. And he further proposes that the textual meaning is the integration of those three metafunctions. Based on Halliday's Systemic-Functional Grammar, most scholars explore metadiscourse from the perspective of function.

For Crismore (1989), metadiscourse has semantic, social, psychological, communicative and rhetorical functions. Those functions have been recognized as projecting writers themselves into texts, guiding and directing, rather than informing readers so that readers can better understand the propositional content of a text as well as writers' attitudes towards the content and their readers. Vande Kopple (2002) proposes that metadiscourse can function as persuasion, for it's an indispensable complement in the persuasive process. Discourse is the combination of proposition and metadiscourse and the latter is the organic element of the discourse. Hyland (2005) states that metadiscourse connects discourse and context together. He highlights the interpersonal function of metadiscourse.

In short, metadiscourse is recognized as an essential means of facilitating communication. For one thing, it helps the writer produce the discourse. For another, it helps the reader understand the primary message and the author's attitude toward the content of the discourse.

\subsubsection{Classifications of Metadiscourse}

With the expanded research field of metadiscourse, its classifications tend to be more specific. The popular classifications are as follows: Vande Kopple's classification, Crismore's classification and Hyland's classification. It is worth noting that these three classifications of metadiscourse are classified from the perspective of vocabulary. This paper takes Hyland's classification as research frame. The reasons are as follows: Firstly, having adopted form Thompson and Thetela's (1995) interactive and interactional concepts, Sinclair's (1981) 'plans of discourse' theory and other previous scholars' classifications Hyland classifies two major categories of metadiscourse-interactive resources and interactional resources. Each one is further divided into subcategories. And his classification emphasizes the interpersonal function of metadiscourse. Secondly, Hyland (2008) points out three key principles of metadiscourse: Metadiscourse is distinct from propositional aspects of discourse; Metadiscourse refers to aspects of the text that embody writer-reader interactions; Metadiscourse refers only to relations which are internal to the discourse. Besides, his classification is based on the research in academic discourse, which makes the classification more concrete and more influential. 
Table 1. Hyland' s (2005, p. 49) classification of metadiscourse

\begin{tabular}{|c|c|c|}
\hline Category & Function & Examples \\
\hline Interactive resources & Help to guide the reader through the text & \\
\hline Transitions & Express relation between main clauses & In addition; but; thus; and \\
\hline Frame markers & Refer to discourse acts, sequences or stages & Finally; to conclude; my purpose is \\
\hline Endophoric markers & Refer to information in other parts of text & Noted above; see Fig; in section 2 \\
\hline Evidentials & Refer to information from other texts & According to $\mathrm{X} ; \mathrm{Z}$ states \\
\hline Code glosses & Elaborate propositional meanings & Namely; e.g.; such as; in other words \\
\hline Interactional resources & Involve the reader in the text & \\
\hline Hedges & Withhold commitment and open dialogue & Might; perhaps; possible; about \\
\hline Boosters & Emphasize certainty or close dialogue & In fact; definitely; it is clear that \\
\hline Attitude markers & Express writer's attitude to proposition & Unfortunately; I agree; surprisingly \\
\hline Self mentions & Explicit reference to author(s) & I, we, my, me, our \\
\hline Engagement markers & Explicitly build relationship with reader & Consider; note; you can see that \\
\hline
\end{tabular}

\subsection{Writing Researches under the Framework of Metadiscourse}

Hyland (2008) considers writing as social interaction. "All writing is motivated by the intention to persuade-to convince our readers to take certain actions, to adopt our world view, to agree with us and like us" (Cheng, 1996, p. 150). The use of metadiscourse in writing is an effective device to turn writer-orientation into reader-orientation. So researches on the relation between metadiscourse and writing constantly spring up.

Firstly, some scholars try to answer the question of whether the teaching of metadiscourse can improve students' writing quality. Through teaching metadiscourse in writing class, Cheng and Steffensen (1996) proved that metadiscourse teaching plays an important role in enhancing students' writing quality. Cheng and Jiang (2004) took Chinese students majoring in English as research subjects, and they found metadiscourse teaching can not only improve students' writing proficiency but also cultivate students' awareness to interact with readers.

Secondly, some scholars try to find the relation between metadiscourse and writing quality. After Intaraprawat and steffensen did research on the ESL students' argumentative essays, they found "Better essays include a wider range of forms and more of metadiscourse. It is proposed that skilled writers have an awareness of the needs of their readers and control the strategies for making their texts more considerate and accessible to the reader. Poor writers, on the other hand, are not able to generate considerate texts (Intaraprawat \& steffensen, 1995, p. 268)".

Finally, some scholars try to answer the question of whether the cross-cultural differences lead to the different use of metadiscourse. After studying on the argumentative essays written by American and Finnish university students, Markkanen, Steffensen, and Crismore (1993) found that the frequency and types of metadiscourse are not the same in those essays written by different language speakers and there are also gender differences.

\section{Research Methodology}

\subsection{Instruments}

The wiring samples are taken from CET-4 which is held twice a year all over the country. And the writing scores are marked by highly trained teachers. As the functions of metadiscourse markers implement in concrete context, that is to say, the same metadiscourse marker may indicate different functions in different contexts. So this study uses the manual method to label metadiscourse markers, avoiding the mechanization of statistical software. The data are analyzed through the Statistical Package for Social Sciences (SPSS) software, version 17.0.

\subsection{Sample}

According to CET-4 marking criteria the writing samples of CET-4, collected from January 2000 to December 2009, are divided into high score writing group (HG), from 11 points to 14 points, and low score writing group (LG), from 5 points to 8 points. Samples were randomly chosen in each group so there are altogether 80 samples. All of those students who take part in CET-4 are from China and Chinese is their mother tongue. They have learned English for at least seven years and are capable to think and write logically with good knowledge of 
grammar and vocabulary.

\section{Results and Discussion}

4.1 Contrastive Analysis on the General Use of Metadiscourse between Two Groups

A univariate analysis of variance is employed to measure whether there are any differences in the quantity and types of metadiscourse markers used in two groups.

Table 2. Comparison in the quantity and types of metadiscourse markers used in two groups

\begin{tabular}{lllll}
\hline Subject & Group & Mean & Std. Deviation & P \\
\hline Quantity & HG & 19.275 & 7.706 & $.019^{*}$ \\
& LG & 15.450 & 6.594 & $.019^{*}$ \\
\multirow{2}{*}{ Types } & HG & 5.800 & 1.244 & .113 \\
& LG & 5.325 & 1.403 & .113 \\
\hline
\end{tabular}

“*”means $p<. \overline{05 .}$

As shown in the above table, the mean score is 19.275 in HG while the mean score is 15.450 in LG. The mean score of HG is higher than that of the LG. $p=.019<.05$ which means that the quantity of metadiscourse markers in HG is significantly higher than that of LG. So it is necessary for the students to pay attention to the readers and then use metadiscourse markers appropriately in writing. Metadiscourse plays an important role in organizing discourse, facilitating the understanding of the content and establishing reliable relation between readers and writers. There isn't significant difference between two groups in types $(p=.113>.05)$, but the mean score of HG is slightly higher than that of LG $(5.800>5.325)$. That is to say, to some extent, the students in HG are aware of the diversity of metadiscourse markers. It should be admitted that the mean scores of both groups are lower than 6, which means that the students neither in HG nor LG are good at using various types of metadiscourse markers to interact with readers.

\subsection{Contrastive Analysis on the Specific Use of Metadiscourse Markers between Two Groups}

To measure whether there are any differences in the specific use of metadiscourse markers between two groups a univariate analysis of variance is used.

Table 3. Comparison in the specific use of metadiscourse markers between two groups

\begin{tabular}{lllll}
\hline Category & Group & Mean & Std. Deviation & P \\
\hline \multirow{2}{*}{ Interactive resources } & HG & 6.475 & 3.693 & $.002^{* *}$ \\
& LG & 4.225 & 2.516 & $.002^{* *}$ \\
Transitions & HG & 4.175 & 2.917 & $.025^{*}$ \\
& LG & 2.925 & 1.845 & $.025^{*}$ \\
Frame markers & HG & 1.700 & 2.053 & .068 \\
& LG & 0.975 & 1.387 & .068 \\
Endophoric markers & HG & 0.000 & 0.000 & .156 \\
\multirow{2}{*}{ Evidentials } & LG & 0.050 & 0.221 & .156 \\
\multirow{3}{*}{ Code glosses } & HG & 0.200 & 0.516 & .807 \\
\multirow{2}{*}{ Interactional resources } & LG & 0.175 & 0.385 & .807 \\
\multirow{2}{*}{ Hedges } & HG & 0.275 & 0.506 & .064 \\
& LG & 0.100 & 0.304 & .064 \\
& HG & 12.825 & 5.679 & .333 \\
& 11.550 & 6.034 & .333 \\
& 1.350 & 1.477 & .079
\end{tabular}




\begin{tabular}{lllll}
\hline \multirow{3}{*}{ Boosters } & LG & 0.875 & 0.822 & .079 \\
& HG & 2.575 & 1.880 & .071 \\
Attitude markers & LG & 1.625 & 1.596 & .071 \\
& HG & 1.100 & 1.257 & .926 \\
\multirow{3}{*}{ Self mentions } & LG & 1.075 & 1.141 & .926 \\
& HG & 3.175 & 3.037 & .888 \\
\multirow{2}{*}{ Engagement markers } & LG & 3.275 & 3.313 & .888 \\
& HG & 4.650 & 3.952 & .727 \\
& LG & 4.350 & 3.690 & .727 \\
\hline
\end{tabular}

“"” means $p<.05 ;$; “*”means $p<.01$.

As can be observed in Table 3, in the use of interactive resources, the mean score is 6.475 in HG while the mean score is 4.225 in LG. $p=.002<.001$ proves that the students in HG use significantly more interactive resources than those used by students in LG. In the use of transitions, the mean score of HG is 4.175 and the mean score of LG is 2.925 , and $p=.025<.05$ shows that students in HG use more transitions than those used by students in LG. This means the students in HG tend to use more transitions to make the writings cohesive.

Apart from transitions, there are no significant differences between two groups in the other subcategories of metadiscourse. But almost the mean scores of subcategories in HG are higher than those in LG. In other words, the students in HG are aware of using interactive resources for the development of discourse and using interactional resources to guide readers to understand their writing intentions. It should be noted that there is "unbalanced use" of the subcategories of metadiscourse. Unbalanced use falls into two categories. For one thing, the mean scores of some subcategories of metadiscourse are too high (transitions and self mentions) or too low (evidentials and endophoric markers). For another, some metadiscourse markers of a certain subcategory are frequently used, but the complicated metadiscourse markers of the same subcategory are seldom used. For example, students usually use but and however to show contrastive relations, but on the contrary and on the other hand are rarely used. In a word, to a great extent, students lack the understanding of metadiscourse, thus they can't appropriately use metadiscourse markers in writing.

As can be seen, both in $\mathrm{HG}$ and LG, the mean scores of interactional resources are higher than those of interactive resources. Does that mean the students pay enough attention to the interpersonal function of interactional resources? The answer is no. It should be noted that, among the 80 samples, 40 of them are argumentative, 12 samples are letters and the topics of other 12 samples relate to campaign speech, voluntary recruit and club announcement. It is no wonder that the mean scores of self mentions and engagement markers are so high. It also proves that quantity and types of metadiscourse markers in writing relate to writing tasks. As can be seen from the table, the mean score of self mentions in HG is lower than that in LG. It is because students with high writing proficiency tend to employ "knowledge conversion mode" in which the students often support the arguments with facts and evidences and they hide themselves and use few self mentions.

\subsection{Research on the Inappropriate Use of Metadiscourse Markers in Two Groups}

What's the relation between the number of inappropriately used metadiscourse markers and writing quality? A Pearson correlation coefficient is used to answer the question.

Table 4. Relation between the inappropriately used metadiscourse markers and writing quality

\begin{tabular}{lll}
\hline Subject & Pearson Correlation & $\mathrm{P}$ \\
\hline Interactive & $.464^{* *}$ & .000 \\
\hline
\end{tabular}

**. Correlation is significant at the 0.01 level (2-tailed).

As can be seen in Table 4, there is a close relation between the inappropriately used metadiscourse markers and writing quality $(p=.000<.01)$. As what has been discussed in 4.1 , there is a positive correlation between the quantity of metadiscourse markers and writing quality. Compared with the quantity of metadiscourse markers $(p$ $=.019)$, the inappropriate use of metadiscourse markers is closer to writing quality $(p=.000)$. 
Table 5. General distribution of the inappropriately used metadiscourse markers

\begin{tabular}{lll}
\hline Subject & Number & Percentage (\%) \\
\hline Transitions & 28 & 50.9091 \\
Frame markers & 5 & 9.0909 \\
Endophoric markers & 1 & 1.8182 \\
Evidentials & 0 & 0 \\
Code glosses & 6 & 10.9091 \\
Hedges & 2 & 3.6363 \\
Boosters & 6 & 10.9091 \\
Attitude markers & 0 & 0 \\
Self mentions & 1 & 1.8182 \\
Engagement markers & 6 & 10.9091 \\
Total & 55 & 100 \\
\hline
\end{tabular}

As shown in Table 5, students make more mistakes in the use of transitions, frame markers, boosters and engagement and fewer mistakes in the use of endophoric markers, hedges and self mentions. The inappropriately used metadiscourse markers can be attributed to: redundancy, default and misuse.

Specifically, the redundancy and default of metadiscourse markers appeared in writing are influenced by negative transfer of the mother tongue, Chinese. For one thing, influenced by the sentence structures of Chinese, students tend to use transitions redundantly. For instance, the structure although... but ... is obviously transferred from Chinese suiran ...danshi... For another, as we know, "parataxis" is a feature of Chinese, so Chinese students' awareness of marking the logical relations is weak, which causes the defaults of transitions. For instance, there are no logical conjunctions to signal additive, causative and contrastive relations between sentences in their writings. Meanwhile, the ambiguous knowledge about the distinctions between words or phrases is the main reason which results in the misuse of metadiscourse. For instance, when students use frame markers to sequence arguments, they mistake at first used to label time order for firstly used to label positional order.

\section{English Writing Teaching Based on Metadiscourse}

"Managing social relationship is crucial in writing because a text communicates effectively only when the writer has correctly assessed both the readers' resources for interpreting it and their likely response to it" (Hyland, 2008, p. 11). So teachers should pay attention to students' understanding and utilizing of metadiscourse.

\subsection{Emphasizing the Input of Metadiscourse}

Proper input is crucial to enhance one's understanding of metadiscourse. Teachers can introduce metadiscourse into Comprehensive English teaching. The texts in Comprehensive English includes general genres, from which teachers can choose model essays as material to explore the functions and types of matadiscourse markers and facilitate students' comprehension on the different using rules of metadiscourse markers in different genres. Besides, teachers can take writing samples as comparative teaching material to improve students' awareness of using metadiscourse. Class teaching is far from enough. Eisterhold (1990) notes that reading passage will somehow function as primary models from which writing skills can be learned or at least inferred. So students can learn how writers organize discourses and convey meanings through vast reading.

\subsection{Improving Students' Audience Awareness}

Written language (spoken language) is considered as social communication between writers (speakers) and readers (listeners) (Hyland \& Tse, 2004). The text is the place where the traction between the writer and the reader happens. Writing is the communicative media between writers and readers, so before and while writing the writer should not only consider the subject and content to be delivered but also take readers' the background knowledge and cognitive ability into consideration. In other words, the writers should establish "audience awareness" which means writers' consideration on readers' information (Kirsh \& Roen, 1990). With the help of internet and library resources, teachers can find discourses, with the same topic to different target audiences. Students will realize the important of establishing audience awareness after comparative reading. 


\subsection{Stressing Writing Practices and Peer Evaluation Teaching}

Swain (1995) outlined three functions of output: 1) the noticing / triggering function, 2) the hypothesis-testing function, and 3) the metalinguistic (reflective) function. Output is an indispensable part in language learning. At first, students should write compositions at least 120 words, within 30 minutes with a given topic. Then, they are divided into groups, each group with 3 or 4 members, and then evaluate compositions among groups. They can absorb others' merits and avoid making the same mistakes in evaluation. Teachers should dwell on the metadiscourse markers which are mistaken frequently and guide students to know it is the quality of metadiscourse markers rather than the quantity that relates to writing quality. At last, it is important to do self-evaluation. Because when they are the readers of their own compositions, they can better survey the using status of metadiscourse markers. This teaching method can improve students' audience awareness and understanding of metadiscourse.

\section{Conclusion}

It can be safely concluded that there is close relation between the quality of metadiscourse markers and writing quality. So teaching metadiscourse is an effective device to improve students' writing proficiency. But in Chinese classroom teaching, matadiscourse is undervalued or even overlooked. Our teachers should employ proper teaching designs to improve students' audience awareness and cultivate their ability to use metadiscourse.

\section{Acknowledgements}

The research is supported by HeBei Education Department Project (2014YYJG068).

\section{References}

Cheng, X. G. (1997). Research on metadiscourse. Dalian: Liaoning Normal University Press.

Cheng, X. G., \& Jiang, H. (2008). Metadiscourse: Yayanyu, yuanhuayu, or yuanyupian? Foreign Languages and Their Teaching, 5, 45-48. http://dx.doi.org/10.3969/j.issn.1004-6038.2008.05.011

Cheng, X. G., \& Steffensen, M. S. (1996). Metadiscourse: A technique for improving student writing. Research in the Teaching of English, 30(2), 149-181.

Crismore, A. (1989). Talking with readers: Metadiscourse as rhetorical act. New York: Peter Lang.

Dafouz Miline, E. (2003). Metadiscourse revisited: A contrastive study of persuasive writing in professional discourse. Estudios Ingelese de la Universidad Complutense, 11, 29-52.

Eisterhold, J. C. (1990). Reading-writing connections: Toward a description for second language learners. In B. Kroll (Ed.), Second language writing: Research insight for the classroom (pp. 88-102). New York: Cambridge University Press. http://dx.doi.org/10.1017/CBO9781139524551.010

Grabe, W., \& Kaplan, R. (1996). Theory \& practice of writing. London and New York: Longman.

Halliday, M. A. K. (1994). An introduction to functional grammar. London: Arnold.

Hyland, K. (2005). Metadiscourse: Exploring interaction in writing. London: Continuum.

Hyland, K. (2008). Metadiscoures. Beijing: Foreign Language Teaching and Research Press.

Hyland, K., \& Tse, P. M. (2004). Metadiscourse in academic writing: A reappraisal. Applied Linguistics, 25(2), 156-177. http://dx.doi.org/10.1093/applin/25.2.156

Intaraprawat, P., \& Steffensen, M. (1995). The use of meta-discourse in good and poor ESL essays. Journal of Second Language Writing, 4(3), 253-272. http://dx.doi.org/10.1016/1060-3743(95)90012-8

Kirsch, G., \& Roen, D. H. (1990). A sense of audience in written communication. Newbury Park, CA: Sage.

Li, Z. W. (2001). Contextualizing functions of metadiscourse. Journal of Foreign Languages, 3, 44-50. http://dx.doi.org/10.3969/j.issn.1004-5139.2001.03.007

Li, Z. W. (2003). Metadiscourse: Linguistic representation of metacognition. Foreign Language Research, 1 , 26-30. http://dx.doi.org/10.3969/j.issn.1005-7242.2003.01.004

Markkanen, R., Steffensen, M. S., \& Crismore, A. (1993). Quantitative contrastive study of metadiscourse: Problems in design and analysis of data. Papers and Studies in Contrastive Linguistics, 28, 137-151.

Thomas, S., \& Hawes, T. P. (1994). Reporting verbs in medical journal articles. English for Specific Purposes, 13(2), 129-148. http://dx.doi.org/10.1016/0889-4906(94)90012-4

Sinclair, J. (1981). Planes of discourse. In S. Rizvi (Ed.), The two-fold voice: Essays in honour of Ramesh 
Mohan (pp. 70-89). Salzburg: Salzburg University Press.

Swain, M. (1995). Three functions of output in second language learning. In G. Cook, \& B. Seildhofer (Eds.), Principle and practice in applied linguistics: Studies in honour of HG Widdowson (pp. 125-144). Oxford, England: Oxford University Press.

Thompson, G., \& Thetela, P. (1995). The sound of one hand clapping: The management of interaction in written discourse. Text, 15(1), 103-127. http://dx.doi.org/10.1515/text.1.1995.15.1.103

Vande Kopple, W. J. (2002). Metadiscourse, discourse, and issues in composition and rhetoric. In E. L. Barton, \& G. Stygall (Eds.), Discourse studies in composition (pp. 91-114). Gresskill, NJ: Hampton Press.

Vande Kopple, W. J. (1985). Some exploratory discourse on metadiscourse. Journal of College Composition and Communication, 36(1), 82-93. http://dx.doi.org/10.2307/357609

Williams, J. M. (1981). Style: Ten lessons in clarity and grace. Glenview, IL: Scott, Foresman and Company.

Yang, X. Z. (2007). Metadiscourse and language functions. Foreign Languages and Their Teaching, 12, 1-3. http://dx.doi.org/10.3969/j.issn.1004-6038.2007.12.001

Yu, J. P. (2007). Genre features and interactional functions of metadiscourse. Chinese Science \& Technology Translations Journal, 20(4), 43-47. http://dx.doi.org/10.3969/j.issn.1002-0489.2007.04.012

\section{Copyrights}

Copyright for this article is retained by the author(s), with first publication rights granted to the journal.

This is an open-access article distributed under the terms and conditions of the Creative Commons Attribution license (http://creativecommons.org/licenses/by/3.0/). 